\title{
NEW APPROACHES TO ACHIEVE SUSTAINABLE REGIONAL DEVELOPMENT
}

\author{
József Káposzta \\ Szent István University, Gödöllő, Hungary
}

We are facing a transnational future. Globalization is getting more and more important in economic development, processes are becoming global, and the allocation of goods, capital and resources is carried out on the global market. In such transnational system, the role of large business centers of resource concentration is getting more significant and the ability of nations to balance the allocation of resources is getting poorer. Consequently, the micro-regions, counties and settlements need to face direct global challenges and the self-generated competition as well. Micro-regions, which are not able to adapt to the global resource market and competition, fall out of this allocation space and surely lag behind. Their future greatly depends on how they can represent their interests and how they can improve their positions.

Keywords: local economic development, financial sources, cluster-based economic development and -planning

\section{Introduction}

Post-industrial network economy of today justifies the two paradigms which are in the focus of my research. Firstly, that social welfare is dominated by the efficiency of the economy (in other way, the allocation of the resources in the economy and society). Secondly, the system-paradigm that basically provides the frame for the moves of modern society, thus for the first paradigm as well. The attention must be called to their practical applicability rather than to their characteristics. I do this in a way that I apply territorial restrictions to the society and examine the realization of economic development.

The economy of Hungary consciously becomes the member of this transnational order. Most of the economic development is due to the state-supported modernization processes absorbing foreign capital and EU funds, since there is scarce national capital for investments. Although such state efforts are strong, they are not enough to eliminate the employment problems and regional underdevelopment that are adverse to the generally accepted social needs. Micro-regions must know that the state does not have impact on the direction and volume of investments because they are primarily influenced by the centers of foreign companies. On the other hand, the financial sources of influencing are also limited, since most of the GDP growth is spent on the state debt and disinflation burdens in long terms. The only way for the micro-regions and counties is to create and use an orientation policy in which they can build on the territorial features and the need for self-sufficient ability. It also influences the willingness to invest both by the state and the foreign investors to enable the region to join the global economic and social transactions. The relations of the world, nations and regions are clearly described by the movements of the society and economy mentioned above, i.e. the network economy of regions. The practical reality of these relations is so general that it is not considered as a problem by those who are not professional.

However, in the background, systems determined by system-paradigm operate, are created, joined, integrated and multiplied etc. in order to survive and develop. Those, who do not understand this mechanism and its coherences, are not able to join this system logistics and thus will be lost.

\section{Material and methods}

If we assume that the first priority of the system is the development of social welfare, we must define the economic development as the basic aim and subsystem. We must call attention to this complicated and difficult problem, representing the social need that urges the economic development of a given area. In the study below I introduce the starting conditions of such a system based on public administration and social coordination, while focusing on the issues listed below:

1. GDP per capita has to be increased dramatically.

2. Economic development has to create a new, efficient resource structure that allows a convertible and lasting growth.

3. Areas have to move from regions motivated by potentials to regions which generate the potentials.

The impacts of the info-communication revolution stimulating the global economy are difficult to identify, but it can be easily perceived that the structure of the economy and the society has significantly changed and similar changes are still underway. The continuality and the speed of such changes are spectacular. The difference in the intensity of how the economies and state regulatory systems are able to follow them is huge (Benett, 2000). It is especially true for the post-socialist nations where the introduction of governance based on social coordination instead of plans and orders caused internal conflicts and challenges. It is not by accident that we can hear more and more about the creation or lack of public administration or regional reforms.

So far I have tried to call the attention to the fact that it is inevitable to apply the system approach in economic development while carrying out tasks related to complicated social and economic phenomena. The state measures such activity of the regions, counties, micro-regions with the GDP per capita. If this indicator is under the average, the region has to line up for resources in the redistribution system of the state, taking the resources from other, more efficient regions. If the national economy is not able to produce GDP that is enough for the "fair resource allocation", it has to apply the next best distribution policy. From that point, it can be clearly seen that the needs decide. In any policy, weak remain to be losers because the safety of the state budget must not be at risk due to the unfavourable effects originating from taking the resources from the strong ones (Bucek, 2005). The next best policies include the one that is called the allocation of external resources as well, which is not under state control. Such allocation is realized, however, based on "market economy" rather than "fairness". A major feature of this policy is that in addition to the participation of the state, it encourages the local governments to enter the global market, increasing their potentials. 
Based on all these, the territorial advantages and disadvantages, the local special problems have to be defined and the development potentials also need to be listed in the starting phase of the local economic development. It should be followed by the definition of development paths (strategies) and of the actions (e.g. human resource development, enterprise development). In the next step, detailed projects and operational programs need to be developed.

Local developments should involve the local players because they need to support the developments and should contribute to the finances as well. An important phase in the process is the evaluation of local actions, sometimes their measurement as well as the feedback.

Planning (strategic management) covers the whole development process. In order to achieve success, personal involvement, proper management and the legitimacy of responsible organization have to be assured in the planning stage of the local economic development. It is impossible to involve all the local players, so such organizations and associations have to be selected that are able to represent the interests of local communities. Local governments are usually the engine of local cooperation (Lengyel and Rechnitzer, 2004). Businesses should also be involved and in ideal cases, educational institutions can also take part in the planning process as well as social groups. The more types of groups say their opinions, the more difficult it is to integrate them in one plan, however, it is easier to gain support from most of the society. The question is whether the oppositions can lead to a real compromise, i.e. to the acceptance of the plan. Involvement therefore requires optimization regarding the number of players and the representation of opinions.

\section{Results and discussion}

Due to their various features, local economic actions can be grouped in many ways. Considering the Hungarian conditions, I focus on three aspects (Blakely and Bradshaw, 2002):

\section{According to sources}

Local economic actions are mainly carried out from local sources, but external financial sources also might be important. Such sources are needed primarily to "start" the actions, but in long terms local sources should be more determinant. Regarding the financial conditions of projects, in long terms (8-10 years) a gradual move to the self-financing and return has to be realized. The question is whether the project can become independent from external sources. The first priority in the financial planning should be to help the projects to become independent from the funds and become financially sustainable.

\section{According to the territorial level and character}

The territorial level of local economic development is local. It does not only mean settlements, parts of larger cities, but micro-regions of settlements or in some cases larger territories. According to certain professional literature, local economy can be interpreted at both regional and national levels. We can distinguish urban, rural areas, associations of settlements, agglomerations of large cities where the focal points of local economic development vary and require various tools and sources. Areas on the Great Plain and in the mountains, tiny settlements, minority villages: these all have different conditions. Various local economic development potentials and needs can be interpreted within cities as well. For example the run-down districts or centers that are becoming uninhabited. Urban and rural areas differ from local economic development aspects. The reason for that is that the urban and rural developments are different even in the Hungarian spatial policy and influence the policies, strategies and through the dedication of funds they have impact on the projects realized. In general, local economy is the space of traditional cooperation between urban and rural areas.

The need for the renewal of urban-rural relations and institutional solutions is getting more and more emphasis among scientists. The approach which deals with the cities and their surroundings as integrated units has already occurred both in the EU and Hungarian thinking in the politics and rhetoric. Urban-rural cooperation is the interest of both cities and small villages; therefore we can find several attempts in countries to harmonize their relations. Unfortunately, there are no clear European samples or answers yet. Cities have always been the centres of their areas and have had influences on their wider surroundings from trade and power point of views. The links between cities and rural areas has become stronger recently which was accelerated by the spread of motorization, the split of residence and workplace, the deepening spatial distribution of jobs and the speed up of urbanization. In addition to the crowded cities, there is greater need for rural natural areas that provide clean environment, food production, recreation and ecological functions. Most of the products made in rural areas can be sold in cities; city people represent the primary market for such products. Thus, the center and its surrounding area have complement roles, providing potentials for local economic development.

\section{According to their features}

Local developments may be physical investments and intellectual developments as well, including the change of approaches and the increase of consciousness. Both of them represent important fields of local developments and both are necessary to enable the area to create its own economic potentials and to improve the cohesion of the community thus increasing the standard of living of local population. In ideal cases, their share is "optimal". It is not enough to make good quality products and to find markets for them, but the demand for such products also has to be created. The thinking of local population should be changed while encouraging conscious consumption. The standard of living also has to be increased to achieve success.

Based on the factors mentioned above, in Hungary mainly the cluster-based local economic development has started to gain space, but it does not have proven solutions yet. Thus, the "competition-strategy" always has to be developed locally, competing in many cases not only with remote regions but with neighbouring ones as well. It means that external consultants can only have some ideas and experience and are able to review development concepts, but plans and strategies need to be developed by local people. Continuous adaptation to fast changing needs, new challenges, and the actions of competitors requires the cooperation of local players. If not, the reactions and replies come slowly and late, leading to the lagging behind of the area. The preparation of documents is not important, but the recognition of real development interests, handling the opposition of interests, dealing with the ongoing changes in a flexible way, i. e. the non-stop management of economic development ideas. It can be realized only by the credible local population and businesses. Consequently, a group needs to be created everywhere to coordinate, organize and manage the local economic development. The bottom-up regional networks are built up from local groups that can have direct impact on the economic development, which can take actions to achieve economic growth (Syrett, 1995). There are groups and associations which represent important local interests (social and religious organization, trade union etc.), but their major role is not the development and elaboration of economic development programs. Such associations do 
not take part in the preparation of strategies and concepts but they review the different versions of plans according to the interests of groups that they represent.

In a region, various networks operate in various structures and with various members. Networks can be distinguished in many ways. According to the competition between the territorial units, there are networks of people, of organizations and networks within organizations. All three have important role in the development of regions. In the competition between territorial units, not individual interests are represented, but aggregated ones, allowing the targeted actions at community level in the spontaneous economic processes. Such initiatives are the essence of regional/local economic development networks. Networks of organizations have two types: the one including businesses (profit-oriented) and the other gathering institutions (non-profit).

The "essence" of networks is a well-operating relationship, continuous conversation between the members and other groups, allowing the solution of conflicts (Young and Kaczmarek, 2000). Regional/local economic development networks are the practical realization of the well-known Triple Helix model, providing answers to new challenges with the collaboration of governments, sectors and scientific institutions (universities). According to the model, local partnerships require the cooperation of four equal local partners ("four legs of local economic development") and constitute the core of regional economic development networks (Lengyel, 2010):

$\square$ Local government sector: mainly the leaders of the local governments and economic institutions.

$\square$ Business sphere: the representatives of chambers, trade unions, professional bodies.

$\square$ Knowledge-transfer institutions: the representatives of secondary-higher education, vocational training, technological-transfer organizations.

$\square$ Development agencies: partly public, partly business agencies. If these four players are able to cooperate, they can organize the clusterbased local economic development efficiently, fast, and considering the spatial development aspects. Taking all these into consideration,

\section{Conclusions}

I believe that in the ever-changing economic environment, increasingly important role has to be played by the educational institutions, including the higher educational ones, since Hungarian developments will be mainly knowledge-based. It is obvious that in a knowledge-based economy, universities play key role, being the suppliers of educated workforce, the organizers of fast and flexible trainings and retrainings and the players of knowledge-transfers etc. it is also an important aspect that higher educational institutions with the help of local communities are able to offset some of the market failures in a knowledge-based economy. It is clear that the role and mission of universities have changed by now. They have important role in the regional and local development in addition to the education and research activities. It is due to the spread of knowledge-based economy which requires renewable and creative human resource. Without such factors, businesses fall out from the global competition. Based on all the above mentioned, I think that the future is in the creation and development of such cooperations and networks that define the development potentials and tendencies of local economies in long terms.

\section{References}

BENNETT, R. J. 2000. Regional and local economic development policy: The role of administration and political entrepreneurs. In: Horváth, Gy. (ed.): Regions and Cities in the Global World. Pécs, Centre of Regional Studies, HAS. pp. 58-81.

BLAKELY, E. J. - BRADSHAW, T. K. 2002. Planning Local Economic Development. Theory and Practice. London : Sage Publications Ltd.

BUCEK, J. 2005. The Role of Local Government in Local Economic Development. Slovakia. In Spkova, S. (ed.): Local Government and Economic Development. Budapest, Open Society Institute. pp. 107-133.

LENGYEL I. 2010. Regionális gazdaságfejlesztés. Versenyképesség, klaszterek és alulról szerveződő stratégiák. Budapest : Akadémiai Kiadó.

LENGYEL I. - RECHNITZER J. 2004. Regionális gazdaságtan. Budapest : Dialóg Campus.

SYRETT, S. 1995. Local Development: Restructuring, Locality and Economic Initiative in Portugal. Avebury, Ashgate Publishing Company.

YOUNG, C. - KACZMAREK, S. 2000. Local government, local economic development and quality of life in Poland. In: GeoJournal, 2000, no. 2-3. pp. 225-234.

\section{Contact address:}

Prof. h.c. Dr. József Káposzta, H-2100 Gödöllő, 1 Páter K. str., Phone: +3628522 000/1900, Fax: +3628522 040, e-mail: kaposzta.jozsef@gtk. szie.hu 